\title{
Human rights theory as solidarity
}

\author{
José-Manuel Barreto
}

\author{
'The state of mind is that of \\ passionate sympathetic contemplation ( $\theta \varepsilon \omega \rho i \alpha)$, \\ in which the spectator is identified with the suffering God, \\ dies in his death, and rises again in his new birth' \\ F.M. Cornford, \\ on the meaning of the word theory in the Dionysian cult \\ I have had no other interest but this: \\ to liberate [the Indians] from the violent deaths \\ which they have suffered and suffer... \\ through compassion at seeing multitudes of people \\ who are rational' \\ Bartolomé de las Casas, in his will
}

Let's formulate some questions that are important for those who are engaged in making theory of human rights but which are rarely thematised: Why do legal theory? Why are scholars interested in elaborating a theory of human rights? A number of answers come to the tip of the tongue: in order justify and advance the cause of human rights; as a way of fulfilling political or ideological commitments; as a result of a commitment to justice or to the enforcement of rule of law; to learn about the phenomenon of the law; because it is part of the business of the academy; out of a professional duty and as a way of earning a living; due to the pleasure of fiddling with theories and abstract thinking. It can also be the consequence of the combination of some or all the above motives.

Above all, let's try a different track to answer these questions. Baxi has complained about how recent and sophisticated Western theories of democracy and human rights ignore the materiality of the violation of human rights or the voices of those who suffer, in a well-established feature of academic common sense that he describes as the 'cruelty of theory' $(2002,14)$. In a similar way, Horkheimer's critique of Kantian morality did not only attack the metaphysical 
way of thinking but it also pointed to the theorists themselves. Horkheimer did not criticise the metaphysical 'forgetting of being' as Heidegger did, but the immoral character of the forgetfulness of the suffering of the wretched of the earth and their struggles in history (Brunkhorst 1993, 78). For Horkheimer, metaphysicians and theorists are scarcely impressed by what torments humanity' and, while their reflections on history and society are irreproachably 'objective', 'suffering or even outrage over justice, or sympathy with victims' are foreign to them (Schmitt 1993, 29).

This inability to look at those who suffer and the retreat of philosophy, critical legal theory and human rights theory 'from the scenes of the battlefield' has to do with their immersion in the intellectual modern culture. A theory indifferent to suffering and obsessed with objectivity or justification is just the expression of the platonic and modern conception of philosophy as theory of knowledge or epistemology. In modernity, to think philosophically supposes a search for objectivity for the conditions that must be present to ensure knowledge can aspire to truth. The question confronting the philosophical effort is that of how the subject can get access to the object in such a way that ideas or concepts attained during this process apprehend the object as it is. This was the hegemonic form that philosophy adopted from the historical dawn of modernity. Having its remote antecedents in Plato, philosophy as epistemology acquired a dominant position with the emergence of transcendental subjectivism. Philosophy dwelled and remained imprisoned within the vicious circle of the relationship between subject and object, which constitutes the plane inhabited by the doubts of Descartes' cogito that aspires to certitude. It is in this realm that the subject takes distance from the empirical world and from common sense and advances towards the transcendental pure a priori, as in Kant. This is also the case of the sphere in which Hegel's dialectic between subject and object occurs and leads to absolute knowledge.

Later, in the context of the 20th century Anglo-North American philosophical tradition, a survey of the ways in which philosophy developed under the Neo-Kantian hegemony shows philosophy as consisting basically of conceptual analysis, explication of meaning, examination of the logic of language and of the structure of the activity of mind (Rorty 1979, 12). In all of these forms of philosophical work, it is also the question of truth and meaning that drives the task of thinking. Thus, the way of thinking inaugurated by the Socrates-Plato partnership, re-launched by Descartes and pursued by Neokantian analytical philosophy, marks modern philosophy with its epistemological character (Rorty 1979, 156-64).

In the human rights arena the epistemological ethos of modern philosophy turns, as in Kant, into a sustained reflection on human dignity, which is deduced from the universal maxims that rule human conduct, namely the different instantiations of the categorical imperative. Turning from anthropology to pure reason, ethical norms are reached by a process in which moral reason takes 
distance from any empirical experience. This 'metaphysics of morals' guarantees the construction of a priori laws, which are necessary and universal and therefore are to be obeyed by all (Kant 1978, 5-6). In one of its formulations, the imperative of pure practical reason prescribes that human beings should never be treated as means alone but also as ends. The consequence derived from the categorical imperative is the principle according to which being human is to be understood as an end-in-itself. This principle sustains the dignity of all human beings that, in turn, becomes the foundation of human rights. The epistemological orientation of modern philosophy has also led the tradition to conceive of the theory of rights as conceptual analysis, in order to make the concept of human rights clear and to define their meaning (Freeman 2002, 2). It also points to an engagement with 'the truth of human rights', namely with a reflection on topics such as the characterisation of human nature, the 'existence' itself of human rights and the definition of what precisely they are (Donnelly 1985, 1).

Rorty believes that the task of thinking should rest on our relations with other human beings and should not be constructed 'in terms of our relation to non-human reality' $(1985,25)$. Platonism and Kantianism have weakened the ability of our culture to 'listen to outsiders' and to be sensitive to those 'who are suffering' (Rorty 1991a, 13). A philosophy overwhelmingly concerned with truth and epistemological subjectivism distracts or distances us from our fellow human beings and blurs our sense of solidarity (Rorty 1999, xv). This is due to the fact that our readiness to note and to become involved with those subjected to pain and humiliation is not cultivated or simply neglected. When philosophy consists basically of a reiterative formulation of metaphysical or epistemological questions, it is natural to forget or to relegate human and social suffering as secondary matters, assuming that they are just appearances or the product of a common sense way of looking at the world (Rorty 1996a, 74). In this intellectual climate suffering becomes an odd topic or even a nonphilosophical theme.

Rorty's critique of Platonic and Kantian epistemological philosophy supposes a prioritisation of ethics over theory of knowledge, and the inclusion of the quest for knowledge within the ethical endeavour. In a move that resembles Levinas' priority of ethics over ontology, Rorty asserts a precedence of ethics over epistemology: knowledge is basically orientated by an ethical and political interest in solidarity $(1991 \mathrm{~b}, 24 ; 27)$. The specifically epistemological duties of a philosophy as solidarity are those of putting together and generalising our intuitions, always with a practical aim, which in some cases could be that of how strengthening the self-awareness, power and efficacy of human rights culture (Rorty 1994, 117).

Rorty attempts, as Dewey did before, a critique of the vision of philosophy as theory of knowledge out of a longing for less cruel and less unjust societies $(1979,13)$. Anti-foundationalism is, in this sense, a move from philosophy 
understood as epistemology to philosophy understood as solidarity. In this framework, objectivity is not the goal of inquiry but the alleviation of the pain others are enduring. The force driving the intellectual adventure is not that of a quest for truth, a love for knowledge, a will to know or a 'desire for an epistemology' (Rorty 1979, 163). Rather, it is an impulse or 'desire for solidarity' (Rorty 1991, 21), for answering the plea of fellow human beings. Our impulse to think and the spontaneous inclination to do philosophy or legal theory come from our 'openness to strangers', from a concern, a preoccupation or an intuitive apprehension for those who are victims of violence. That openness allows us to be witness to the suffering of others and to cultivate inside us a fellow feeling (Rorty 1979, 9). In this perspective the pursuit of freedom, solidarity, and human rights and the struggle against oppression, humiliation and cruelty are the forces driving philosophical inquiry (Rorty 1989, xiii).

The ethics of sympathy developed within the ambit of Critical Theory can also be drawn into this discussion on the nature of theory. If the basic interest of Critical Theory is, according to Horkheimer, that of 'striving to reduce suffering' (McCarthy 1993, 138), theory acquires an ethical drive and takes the form of an 'existential judgement' (Brunkhorst 1993, 72). It is said that Adorno was also close to this impulse, as sympathy with the suffering of the victims of violence acted as motivation of his thinking (Morchen, cited in Garcia-Duttmann 2002, 6). If the experience of individual suffering is at the basis of social criticism (McCole 1993, 18), then the main object of theory is not the search for truth but rather the practical aim of the alleviation of pain. But again, such an object is not defined in abstract or rationalistic terms: the relief of the suffering — which is human, both individual and social, and that of past, present and future generations - becomes the teleology of morality and theory, and the political motive of the critical theorist.

The idea of philosophy as solidarity has, as a consequence, a partisan conception of philosophy. In an epistemologically orientated theory the subject is in front of the object - society or the world — and just in front of it, being in this way a spectator. To step outside or to remain at a distance from the society with which we are dealing is assumed to be a necessary condition for objective knowledge. This would allow the analysis of a particular society from a universal or transcendental point of view. This does not occur in a philosophy built out of a feeling of sympathy or solidarity. In this scenario, the one who knows is a participant who reflects upon the situation and acts upon it (Rorty 1979, 18-19). Those developing theory are engaged in a relation with those under scrutiny, occupied in learning how to deal with the situation in which others are involved, and eager to make a contribution to that community. Theory is conceived of as 'cooperative human inquiry' and the Neopragmatist philosopher is seen as a 'partisan of solidarity' (Rorty 1991, 21; 24) - as somebody who serves the community (Rorty 1996b, 17). 
The implications of such a conception of philosophy are present in Rorty's theory of human rights. Human Rights, Rationality and Sentimentality, Rorty's only piece entirely dedicated to reflect on human rights, begins with the image of a Muslim man being physically and psychologically destroyed on the orders of his Serbs captors in Bosnia. This text later develops into a meditation about long term cultural strategies that ensure this kind of atrocities do not happen again. In a more traditional tone, Michael Freeman's Human Rights begins with a story about the fate of a Pakistani teenager who is raped, handed by the police to her family and finally murdered as a punishment for dishonouring her tribe. Maintaining that 'the analysis of the concept of human rights... must be combined with a sympathetic understanding of the human experiences to which the concept refers', and assuming that 'we sympathise with the victims', Freeman goes on to develop his chapter on Thinking about Human Rights (2002, 2-3). In a similar sense Costas Douzinas describes his The End of Human Rights as 'a critique of legal humanism inspired by a love of humanity' (2000, vii). The rhetorical devices used here to begin the analysis give us a clue about the origins or the compulsion that leads the theorist to think about human rights in the first place.

Rorty's Neopragmatism ends up as being a 'philosophy of solidarity' as hope, freedom and human rights substitute knowledge, truth or objectivity as guides of thinking $(1991,33)$. Theory is not created by a love of knowledge. It is openness to others and a desire for solidarity that makes us to think of rights. The theory of human rights is developed by theorists witnessing the pain of others and out of a desire to reduce their suffering. The human rights scholar wants to get involved and to intervene, and to take the side of the victim - of all victims - against all perpetrators. To be in front of those who are victims of cruelty, humiliation and oppression, and to look at the face of those who suffer are the experiences that give birth to the theory of human rights. Theories in general and legal theory in particular are consequences of sympathy. Human rights theory is solidarity.

\section{Bibliography}

Baxi, U. (2002) The Future of Human Rights (Delhi \& Oxford: Oxford University Press).

Brunkhorst, H. (1993) 'Dialectical positivism of happiness: Horkheimer's materialist deconstruction of philosophy', in S. Benhabib et al. (eds.), On Max Horkheimer. New Perspectives (Cambridge, MA \& London: MIT Press).

Donnelly, J. (1985) The Concept of Human Rights (London: Croom Helm).

Douzinas, C. (2000) The End of Human Rights (Oxford: Hart).

Freeman, M. (2002) Human Rights: An Interdisciplinary Approach (Malden, MA: Polity). 
Garcia-Duttmann, A. (2002) The Memory of Thought. An Essay on Heidegger and Adorno (London \& New York: Continuum).

Kant, I. (1978) Foundations of the Metaphysics of Morals (Indianapolis, IN: Bobbs-Merrill).

McCarthy, T. (1993) 'The idea of a critical theory and its relation to philosophy', in S. Benhabib et al. (eds.), On Max Horkheimer. New Perspectives (Cambridge, MA \& London: MIT Press).

McCole, J. et al. (1993) 'Max Horkheimer: between philosophy and social science', in S. Benhabib et al. (eds.), On Max Horkheimer. New Perspectives (Cambridge, MA \& London: MIT Press).

Rorty, R. (1979) Philosophy and the Mirror of Nature (Princeton, PA: Princeton University Press).

Rorty, R. (1989) Contingency, Irony and Solidarity (Cambridge: Cambridge University Press).

Rorty, R. (1991a) 'Introduction', in R. Rorty, Objectivity, Relativism and Truth. Philosophical Papers I (Cambridge: Cambridge University Press)

Rorty, R. (1991b) 'Solidarity or objectivity', in R. Rorty, Objectivity, Relativism and Truth. Philosophical Papers I (Cambridge: Cambridge University Press).

Rorty, R. (1994) 'Human rights, rationality and sentimentality', in S. Shute and S. Hurley (eds.), On Human Rights: The Oxford Amnesty Lectures 1993 (New York: Basic Books).

Rorty, R. (1996a) 'Heidegger, Kundera and Dickens', in R. Rorty, Essays on Heidegger and Others. Philosophical Papers. Volume 2 (Cambridge \& New York: Cambridge University Press).

Rorty, R. (1996b) 'Philosophy as science, as metaphor and as politics', in R. Rorty Essays on Heidegger and Others. Philosophical Papers. Volume 2 (Cambridge \& New York: Cambridge University Press).

Rorty, R. (1999) Philosophy and Social Hope (London: Penguin).

Rorty, R. (2000) 'Universality and truth', in R. Brandom (ed.), Rorty and his Critics (Abingdon: Blackwell).

Schmitt, A. (1993) 'Max Horkheimer's intellectual physiognomy', in S. Benhabib et al. (eds.), On Max Horkheimer. New Perspectives (Cambridge, MA \& London: MIT Press). 